\title{
Profitability Factors On Bank Muamalat Indonesia
}

\author{
M. Askari Zakariah, Fitri Kumala Sari, Hamzulyana \\ Institut Agama Islam Al Mawaddah Warrahmah Kolaka, alanal \\ JL. Pondok Pesanteren No. 10 Kel. Lamakato, Kolaka, Sulawesi tenggara \\ Email: askari@iaialmawar.ac.id
}

\begin{abstract}
Indonesian crisis on 1998 have affected to Bank condition. Bank Muamalat Indonesia (BMI) have Islamic principle on mechanism process such as profit sharing. This study aims to determine and analyze how much influence these factors have on Bank Muamalat Indonesia's profitability (ROA). Methodology of research by Multiple linear regression based on open data profitability, factors tested were financing to deposit ratio (FDR), non performing finance (NPF), and operational expenditure on operating income (BOPO). Result showed that formula $\mathrm{R}$ square is 0.99 , analysis of variance significant, FDR have a positive effect significant to ROA. However, Operational expenditure on operating income (BOPO) have a negative effect significant. Concluded that factor FDR and BOPO have affected profitability on Bank Muamalat Indonesia in 2013-2018.
\end{abstract}

Keywords: Profitability, Financing deposit ratio, Non performing finance

\begin{abstract}
Abstrak
Krisis Indonesia pada tahun 1998 telah mempengaruhi kondisi perbankan. Bank Muamalat Indonesia (BMI) salah satu bank yang memiliki prinsip syariah yang dalam operasionalnya menjalankan prinsip bagi hasil. Penelitian ini bertujuan untuk mengetahui dan menganalisis seberapa besar pengaruh variabel bebas terhadap profitabilitas Bank Muamalat Indonesia (ROA). Metodologi penelitian dengan Regresi Linier Berganda. Faktor yang diuji adalah rasio pembiayaan terhadap deposito (FDR), keuangan bermasalah (NPF), dan pengeluaran operasional untuk pendapatan operasional (BOPO). Hasil penelitian menunjukkan bahwa $\mathrm{R}$ square adalah 0,99. FDR berpengaruh positif dan signifikan terhadap ROA. Namun, biaya operasional pendapatan operasional (BOPO) berpengaruh negatif dan signifikan. Disimpulkan bahwa faktor FDR dan BOPO mempengaruhi profitabilitas pada Bank Muamalat Indonesia pada tahun 2013-2018.
\end{abstract}

Kata kunci: Profitabilitas, FDR, NPF

\section{INTRODUCTION}

The first Islamic bank in Indonesia, PT Bank Muamalat was established in 1991 and began its operational operations in May 1992. The establishment of Bank Muamalat Indonesia (BMI) was initiated by the Indonesian Ulama Council 
(MUI) which was activated by Muslim businessmen and scholars (Marimin and Romdhoni, 2015). BMI is the first bank in Indonesia to carry out its activities based on Islamic principles. As a bank, BMI continues to operate the same as other conventional banks as long as they do not argue with sharia principles. BMI is inseparable from efforts to achieve worldly gain but is balanced with gains hereafter or in this case to achieve profit and heaven (world and the hereafter). In addition, BMI also must adhere to the principle of Prudential Banking, namely the principle of bank prudence in the context of business in order to remain in conditions that support and meet the criteria of a healthy bank. In this case there are provisions that regulate funds issued by banks for funds issued by banks for funds issued by the public. One of the provisions in Bank Muamalat Indonesia is the risk management division, namely management controls risk.

Bank Muamalat Indonesia plays important role in the National financial system. the establishment of Islamic banking was initially dubious, many parties assumed that the interest-free banking system was impossible and unusual. However, when the economic crisis in 1997-1998 there was a monetary crisis in Indonesia, the first Islamic bank established in Indonesia, namely PT Bank Muamalat Indonesia (BMI) could prove its resilience during the 1997-1998 crisis. Despite the decline in profits earned, Bank Muamalat, which basically uses the principle of profit sharing, survived the crisis due to its varied products, such as the example of Murabahah products that were not affected by fluctuations in the BI rate, so the real sector that used these funds also survived adverse effect of the BI rate increase. different from what was experienced by conventional banking, which at that time caused 16 banks to be closed (liquidated) (www.infobanknews.com). This proves that Islamic banks which in their business activities use a profit sharing system instead of relying on interest in this case usury which is forbidden in Islamic Business Islamic banks are able to survive amid the monetary crisis at that time.

Profitability is the most appropriate indicator to measure the performance of a bank. The higher the profitability, the faster the acceleration of growth of Islamic Bank assets in Indonesia so that it reaches an economically efficient scale. The measure of profitability used in the banking industry is Return On Assets (ROA). ROA is a ratio used to measure the ability of bank management to obtain 
overall profits. The greater the bank ROA the greater the level of profit achieved by the bank and the better the bank's position in terms of usage.

The ability to generate profit (profitability) is very influential in improving the performance of the growth and development of PT BMI itself. Because in increasing the growth of the bank there is a need for a component that can support the level of success in achieving it, namely the amount of profit earned. The high profitability shows that PT BMI has a good performance, especially in terms of generating profits. The low profitability indicates that it lacks good performance, especially in terms of generating profit / profit.

Bank Muamalat Indonesia Tbk since a number of years ago recorded a less favorable financial performance. Ranging from large non-performing financing (NPF), shrinking capital, to a high operational burden. There is a need for effort in the growth and development of profitability of Bank Muamalat Indonesia by looking at the factors that influence it, it can be possible for efforts to encourage better profitability growth. The factors that influence profitability (ROA) that the researcher can conclude are the Financing To Deposit Ratio (FDR) factor related to the bank's business in liquidity management, the difference between the amount of financing provided by the bank and the amount of third party funds received by banks, Non Performing Financing ( NPF) related to problem financing and how the quality of assets obtained by bank banks. Operational Income Operational Income (BOPO) is related to the cost of costs and income of the bank itself in carrying out its business operations. With this study aims to determine and analyze how much influence these factors have on Bank Muamalat Indonesia's profitability (ROA). So that researchers are interested in conducting research with the title: "Analysis of Factors Affecting the Profitability of PT Bank Muamalat Indonesia (BMI)".

\section{LITERATURE REVIEW}

\section{Characteristics of Factors Affecting Profitability}

Bank profitability is a bank's ability to generate profits by utilizing assets held in a given period (Mawaddah, 2017). Profit (profit) is excess income compared to the amount of costs incurred to obtain this income. Analysis of profitability is very important for all users, especially investors and creditors. For investors, profit is the only determinant of changes in the value of securities. For 
creditors, profits are generally sources of interest and principal financing. The profitability assessment of Islamic banks is intended to assess the ability of banks to generate profits.

Profitability is a measure of profits obtained by Islamic financial institutions. As the definition of profitability is a ratio that measures the overall effectiveness of management aimed at the size of the level of profits obtained in relation to sales and investment. One of the objectives of managing a financing portfolio is for profitability. Namely to obtain the results of financing in the form of profits earned from profit sharing obtained from businesses managed with customers. Increased profitability is good news for Islamic Banking. Profitability is measured using profit margin, which is net income divided by sales (Asiyah, 2017).

In Islamic banking, revenue is the proceeds received by banks from channeling funds (investments) into productive assets, namely the placement of bank funds on other parties. This is a difference or more number than earning assets with the proceeds of bank receipts. Islamic banks introduce a system of profit sharing to the community with the term Revenue Sharing, which is a revenue sharing system that is calculated from total management revenue and without deducting the cost of managing funds (Wiroso, 2005). Whereas in profit sharing profit sharing is calculated from income after deducting costs which are directly related to the management of murabahah funds (Wiyono, 2005).

Profitability is the most appropriate indicator to measure the performance of a bank. Bank performance is a description of the condition of the bank in a certain period. To measure the level of profitability, the Return of Assets (ROA) ratio is used because Bank Indonesia as the supervisor and banking supervisor prioritizes the value of a bank's profitability as measured by assets originating from a large portion of public savings funds. The greater the ROA of a bank the greater the level of profit of a bank and the better the bank's position in terms of asset use.

Differences in the level of profitability of ROA Islamic banks are influenced by many factors. One of the factors that affect the profitability of ROA is the characteristics of the bank. Each bank has different characteristics so that the level of profitability of the bank also varies. Explaining bank characteristic 
variables containing bank financial ratios starting from total financing, capital, bank activities and productive assets can affect bank profitability (Ardana, 2017).

According to Bank Indonesia, ROA is a comparison between pre-tax profit and the average total assets in one period. The greater the ROA shows the better the company's performance, because the return is greater. So that in this study using ROA as an indicator measuring the financial performance of banking companies. Profit is the goal for the following reasons: (a) With sufficient profit, shareholders' profits can be divided and with the approval of the shareholders, part of the profit is set aside as a reserve. Additional reserves will increase the credibility (trust level) of the bank in the eyes of the public. (b) Profit is an assessment of leadership skills. Capable and skilled bank leaders can generally bring greater profits than less capable leaders. (c) Increase attractiveness for capital owners (investors) to invest their funds by buying shares issued or determined by the bank. So that the bank will have the capital power to expand its product and service offerings to the community. Therefore, bank management in practice is required to be able to meet the set targets (Yusuf and Mahriana, 2016).

ROA is a ratio used to determine the ability of banks to generate profits from the management of assets owned by the Bank. ROA as a measure of profitability can see the achievement of profit of a Bank. This is because assets are assets of the Bank whose funds come from a large portion of the people's savings funds. Efficient use of assets in generating profits can be shown from the greater ROA owned by the company (Haq, 2015). The characteristics of the Bank's financial ratios that affect profitability are Liquidity With Financing To Deposit Ratio (FDR), asset quality with Non Performing Financing (NPF) and Operational Income Operating Ratio (BOPO).

\section{Financing To Deposit Ratio (FDR)}

Financing To Deposit Ratio (FDR) The ratio between the amount of financing provided by banks and third party funds received by FDR banks is determined by a comparison between the amount of financing provided with public funds collected, which includes demand deposits, time deposits (deposits) and savings. The FDR states how far the bank's ability to repay funds withdrawals made by depositors by relying on financing provided as a source of liquidity 
(Rizkika and Dillak, 2017). According to the large Indonesian dictionary, liquidity is the position of a company's cash money and its ability to fulfill obligations that are due on time; the ability to fulfill the obligation to pay debt and so on (about the company and so on) or the liquidity of the bank's ability at any time to pay off its short-term debt if it is suddenly billed (Poerwadarminta, 2003). Maintaining liquidity can be done by paying attention to seasonality, which is to learn when the withdrawal time is large, small or with the average daily withdrawal of money (Indonesian Bankers Association, 2018)

FDR is a ratio that measures the ability of banks to fulfill financial obligations that must be fulfilled immediately. The obligation is in the form of call money which must be fulfilled when there is a clearing obligation where fulfillment is carried out from current assets owned by the Bank (Rizkika and Dillak, 2017).

This ratio is used to measure the extent to which loan funds are sourced from third party funds. This high and low ratio shows the level of liquidity of the bank. So that the higher the FDR number of a bank, it means that it is described as a less liquid bank compared to banks that have a smaller ratio ( and Megawati, 2015).

Bank Indonesia stipulates that the amount of the FDR must not exceed $110 \%$. Which means the bank by providing financing exceeds the amount of third party funds that have been collected as long as it does not exceed $110 \%$ (Arifin, 2010). Because the funds collected from the community are few, the bank in this case can also be said not to carry out its function as an intermediary (intermediary) properly. The higher the FDR shows the more risky bank liquidity conditions, on the contrary the lower the FDR indicates the lack of effectiveness of banks in channeling financing. If the bank's FDR ratio is at a standard set by Bank Indonesia, then the profit obtained by the bank will increase (assuming the bank is able to channel its financing effectively). If you want to maintain your liquidity position by increasing your cash reserves, the bank will not use all of the existing loan-able funds because some are returned in cash reserves, this means that the effort to achieve profitability will decrease. Conversely, if the bank wants to enhance profitability, then the cash reserve for liquidity is used by the bank's business, so that the liquidity position will decrease. If this ratio increases within a certain limit, more funds will be channeled in the form of financing, so that it 
will increase the bank's profit, assuming the bank distributes funds for effective financing. With increasing profits, Return on Assets (ROA) will also increase, because profit is a component that forms ROA (Suryani, 2011).

\section{Non Performing Finance (NPF)}

Non Performing Finance (NPF) includes credit where the guarantor cannot implement the terms of the credit agreement that has been signed, which is caused by various things so that it needs to be reviewed or changes to the agreement. Thus, there is a possibility that credit risk can increase. Based on Bank Indonesia circular letter No. 17/19 / DPUM in 2015, set the NPF for sharia commercial banks as low as 5\% (Rizkika and Dillak, 2017).

In general, the strategy implemented as a problematic financing settlement effort can be grouped into 2, namely: stay strategy is a strategy when the bank still wants to maintain business relationships with customers in a long time context, phase out strategy is a strategy when the bank does not want to continue business relations again with the customers concerned in the context of a long time (Sholihin, 2013).

\section{BOPO (Operational Expenditures on Operating Income)}

Operational expenditure on operating income is the ratio used to measure the level of efficiency and capability of Islamic banking in carrying out its operational activities (Hartini, 2016). From this ratio, it can be seen the level of efficiency of management performance of a bank (Huda, 2014). The sources of income for sharia banks consist of profit sharing on murabahah contracts and musyarakah contracts, profits from contracts of sale and purchase, rental fees and administrative fees for other services (Arifin, 2009). BOPO is calculated using the following formula: BOPO = Operating costs / Operating income.

\section{Relevant Research.}

Sineba Arli Silvia (2017) Sharia and Islamic Economics Department of STAIN Curup with the research title "The Effect of Asset Quality on Profitability in Islamic Banking in Indonesia" with CAR research results positively influences ROA, meaning that high or low CAR can predict high or low ROA. FDR has a positive effect on ROA, meaning high or low FDR can predict high or low ROA. 
NPF does not have a negative effect on ROA, because the average NPF value of Islamic banks in Indonesia is relatively low so it is assumed that the level of bad loans is also low and does not have an effect on the profits of Islamic banks. BOPO has a negative effect on ROA, meaning that the high BOPO can predict low ROA, and vice versa the low BOPO can predict high ROA.

Based on these studies there are similarities with this research which is using the method of multiple regression analysis. And the difference in this research is in the variables used by Sineba Arli Silvia.

Ubaidillah (2016) Faculty of Economics and Islamic Business IAIN Purwokerto, with the research title "Analysis of Factors that Influence the Profitability of Islamic Banks in Indonesia". with the results of the study stating that:

First, Based on the results of statistical calculations with the t test shows that the Financing to Deposit Ratio (FDR) variable has a positive and significant effect on Return On Assets (ROA). This shows that if the ability of banks to channel financing to third party funds collected is high, the higher the funding provided to the bank and also to increase bank profit (ROA), in other words the increase in Financing to Deposit Ratio (FDR) will increase ROA, so that the bank's financial performance will be better.

Second, Based on the results of statistical calculations with the t test showing that the Non Performing Financing (NPF) variable has no significant effect on profitability (ROA). During the study period, the level of Islamic banking Non Performing Financing (NPF) was still low, which was below 5\%. So that the banking party needs to be careful in carrying out its functions. Risks in the form of difficulties in repaying financing by a debtor with a considerable amount can affect the performance of the bank. The existence of problematic financing causes a lot of channeled financing that does not provide results.

Third, Based on the results of statistical calculations with the t test showing that the Operational Cost per Operational Income (BOPO) variable has a significant negative effect on the level of profitability (ROA). This shows that the decreasing BOPO level indicates the higher operational efficiency achieved by the company, which means that the bank assets are more efficient in generating profits.

Based on the results of research conducted by Ubaidillah, it has similarities and differences with the research that the researchers did. The equation is located in his research on the analysis of factors that influence the profitability of Islamic banks. But the difference lies in the study sample. Research Ubaidillah has three sample criteria, namely PT. Bank Muamalat Indonesia, Bank Syariah Mandiri, and Bank Mega Syariah Mandiri while researchers used one sample, namely PT. bank muamalat Indonesia. 


\section{Research Hypothesis}

The hypothesis is a provisional or provisional formulation. Based on these definitions, the formulation of the hypothesis in this study are as follows:

Ho1: There is no positive and significant effect of liquidity or financing to deposit ratio (FDR) on profitability at PT Bank Muamalat Indonesia.

Ha1: There is a positive and significant effect of liquidity or financing to deposit ratio (FDR) on profitability at PT Bank Muamalat Indonesia.

Ho2: There is no positive and significant effect of the quality of assets or Nonperforming financing (NPF) on profitability at PT Bank Muamalat Indonesia.

Ha2: there is a positive and significant effect of the quality of assets or Nonperforming financing (NPF) on profitability at PT. Bank Muamalat Indonesia.

Ho3: there is no positive and significant effect of operating income operational costs (BOPO) on profitability at PT Bank Muamalat Indonesia

Ha3: There is a positive and significant effect of operating income operational costs (BOPO) on profitability at PT Bank Muamalat Indonesia.

\section{METHODS}

The approach of this research is quantitative, namely research that emphasizes theory testing through measuring research variables with numbers and analyzing data with statistical procedures. this study used a type of Causal Associative research. Associative causal can be used by knowing the relationship of two or more variables. Associative research is intended to find out how much influence the independent variables are financing to deposit ratio (FDR), asset quality with Non-performing financing (NPF) and operating income operating costs (BOPO) on the dependent variable, namely profitability that measures by ratio $\mathrm{ROA}$.

The research was conducted at PT. Bank Muamalat Indonesia. Bank Muamalat was chosen as the object of research because Bank Muamalat Indonesia (BMI) was the first Sharia Commercial Bank established and operating in Indonesia, established in 1991 and started its operations in May 1992. It was the first bank in Indonesia to operate its activities based on Islamic principles 
based on partnership and still increasing its profitability. The research comes from open quarterly financial report data published through the official website of Bank Indonesia and Banak Muamalat Indonesia https://www.bankmuamalat.co.id. This research will be conducted on December 27, 2018-28 January 2019. It is hoped that it will be able to collect the data needed in accordance with the specified time.

The design of this study starts from quantitative problems and limits the problems that exist in the formulation of the problem. Problem formulation is stated in the sentence sentence, then the researcher uses the theory to answer it. This consists of two variables, namely the independent variable $(\mathrm{X})$, namely liquidity (FDR), asset quality (NPF) and BOPO and related variables (Y), namely protitability (ROA) in Islamic banks.

Population is the whole object of good research consists of real objects, abstracts, events and symptoms which are data sources and have certain and similar characters. The population used as the sample in this study is a sharia commercial bank in the regency of Southeast Sulawesi. The sampling technique in this study was purposive sampling method. purposive sampling is a method of selecting samples based on certain criteria and considerations. Determination of purpose using purposive sampling method with the following criteria: (a) Sharia commercial banks that have branches in the collector districts and have been operating for the period 2013-2018. (b) Publish quarterly financial statements in the period 2013-2018 and have been published on the bank Indonesia website and the bank's official website. (c) Data for research is available between 20132018.

The data used in this study uses secondary data. Secondary data is data obtained not from the source directly but collected by other parties and the data has been processed. This secondary data in the form of evidence, records or historical reports that have been arranged in archives (documentation data) that are published or unpublished. The data taken in this study is the publication of quarterly PT Bank Muamalat Indonesia's financial statements based on data from the 2013-2018 period.

The data sources in this study were obtained from the official website of Bank Indonesia, namely https://www.bi.go.id/id/Default.aspx and the official website of PT. Bank Muamalat Indonesia https://www.bankmuamalat.co.id 
about the publication of quarterly financial statements of PT Bank Muamalat Indonesia (BMI), namely quarterly financial statements for calculating BMI financial ratios.

The data analysis technique used to test the hypothesis is by using multiple linear regression data analysis techniques using SPSS 14 software after all the required data is collected then the data is analyzed.

Multiple Linear Regression

The analysis tool used to determine the effect of independent variables, Non Performing Financing (NPF), financing to deposit ratio (FDR), and Operational Income Operating Costs (BOPO) on Return on Assets (ROA) is to use multiple regression analysis. Regression analysis is basically a dependent variable (bound) study with one or more independent variables (explanatory / free variables), with the aim of estimating and / or predicting the population average or the average value of the dependent variable based on the value of the known independent variable .

$\mathrm{Y}$ is assumed as profitability (ROA), $\mathrm{X}$ is assumed to be FDR, NPF and BOPO, so: $\mathrm{Y}=\mathrm{ROA}$

From the equation above, it is obtained,

$\mathrm{Y}=\mathrm{a}+\mathrm{b} 1 \mathrm{X} 1+\mathrm{b} 2 \mathrm{X}_{2}+\mathrm{b}_{3} \mathrm{X}_{3}+\mathrm{e}$

\section{RESULT AND DISCUSSION}

\section{Determination Coefficient Analysis (R2)}

In this statistical calculation the value of $\mathrm{R} 2$ used is adjusted $\mathrm{R}$ square. Adjusted $\mathrm{R}$ square is an indicator used to determine the effect of adding an independent variable into a regression equation. The adjusted $\mathrm{R} 2$ value has been freed from the influence of the degree of freedom, which means that the value has really shown how the influence of the independent variable on the dependent variable.

Based on the $\mathrm{R}$ test to see how much influence the Independent variable has on the dependent variable, with a summary model. Based on the results of the coefficient of determination $\mathrm{R}$ test which shows that $\mathrm{R}$ square is equal to 0.994, it means that the results of the ability of the independent variable to explain the size of the dependent variable are $99.4 \%$. This shows that $99.4 \%$ of profitability can be 
explained by the independent variables used in the model (FDR NPF and BOPO) and the remaining $1.6 \%$ is explained by other variables outside the model used.

Table 2

Analysis of variance of formula regression

\begin{tabular}{|c|c|c|c|c|c|c|}
\hline \multicolumn{2}{|c|}{ Model } & $\begin{array}{c}\text { Sum of } \\
\text { Squares }\end{array}$ & Df & Mean Square & $\mathrm{F}$ & Sig. \\
\hline 1 & Regression & 7.463 & 3 & 2.488 & $1.246 \mathrm{E} 3$ & $.000^{\mathrm{a}}$ \\
\hline & Residual & .038 & 19 & .002 & & \\
\hline & Total & 7.501 & 22 & & & \\
\hline
\end{tabular}

Based on the results of the F test above using variance analysis or ANOVA can be seen a significant value $(0.00<0.05)$ which means significant, it can be concluded that the independent variable X1 Financing To Deposit Ratio (FDR), $\mathrm{X} 2$ Non Performing Financing (NPF), X3 Operating Costs Operational Income (BOPO) has a significant influence on profitability (return of assets) dependent variable $(\mathrm{Y})$.

Based on the results of the $\mathrm{F}$ test above using variance analysis or ANOVA can be seen a significant value $(0.00<0.05)$ which means significant, it can be concluded that the independent variable X1 Financing To Deposit Ratio (FDR), X2 Non Performing Financing (NPF), X3 Operating Costs Operational Income (BOPO) has a significant influence on profitability (return of assets) dependent variable $(\mathrm{Y})$.

Table 3.

Multiple linear regression

\begin{tabular}{|c|c|c|c|c|c|}
\hline \multirow[b]{2}{*}{ Model } & \multicolumn{2}{|c|}{ Unstandardized Coefficients } & \multirow{2}{*}{$\begin{array}{c}\text { Standardized } \\
\text { Coefficients } \\
\text { Beta }\end{array}$} & \multirow[b]{2}{*}{$\mathrm{T}$} & \multirow[b]{2}{*}{ Sig. } \\
\hline & B & Std. Error & & & \\
\hline 1 (Constant) & $7 \cdot 955$ & .333 & & 23.870 & .000 \\
\hline FDR & .010 & .002 & .130 & 6.240 & .000 \\
\hline NPF & .005 & .009 & .012 & .580 & .568 \\
\hline $\mathrm{BOPO}$ & -.089 & .002 & -.923 & -36.830 & .000 \\
\hline
\end{tabular}

This test is conducted to find out whether the independent variables have a partial positive effect on the dependent variable based on existing regression results. The $t$ test is done by comparing the value of $t$ count and $t$ table. If $t$ count $>$ $\mathrm{t}$ table then $\mathrm{Ho}$ is rejected while $\mathrm{H} 1$ is accepted, where the independent variable 
in question has a significant influence on the dependent variable. Conversely, if $t$ count $<\mathrm{t}$ table then it is concluded

1) First, Based on the results of statistical calculations with the test showing that the variable X1 Financing to Deposit Ratio (FDR) is 6.240 with a significant level of 0.00 , because the significant level is $0.00<0.05$, thus Ha1 is accepted, that partially FDR has a significant effect to profitability.

2) Second, Based on the results of statistical calculations with the t test showing that the variable X2 Non Performing Financing (NPF) is equal to .568 with a significant level of 5.68 , because the level is significant $5.68>0.05$, Ha2 is rejected, that NPF partially has no effect significant to profitability.

3) Third, Based on the results of statistical calculations with the test showing that the variable $\mathrm{X}_{3}$ Operational Cost per Operational Income (BOPO) is $-36,830$ with a significant level of 0.00 , because the significant level is $0.00<0.05$ then Ha3 is accepted, that partially BOPO FDR has a significant effect on profitability.

From the results of the FDR variable $\mathrm{X} 1$ regression test equation has a positive effect $($ regression coefficient $=0.010)$ and significant $(0.000<0.05)$ where the value of $t$ count is $6.240>t$ table $=(2.09)$. Thus, the decision was made to reject Ho1 and accept Ha1. Based on the analysis of the mean 94.80652. That if the bank's ability to channel financing to third party funds is high, the higher the financing provided to the bank and also will increase the profitability (ROA) of PT Bank Muamalat Indonesia. In other words, FDR will increase ROA so that the bank's financial performance will improve. FDR is the ratio of the difference between the amount of financing channeled by banks to the public and the amount of third party funds collected by the bank muamalat Indonesia.

FDR is a ratio used to pay attention to and improve its financial condition with efforts to prevent liquidity risk which might occur if it does not pay attention to FDR. The occurrence of risk can cause the bank to not be able to return the customer funds used and the possibility of the customer not trusting the bank to save the funds again. The higher the FDR, the higher the funds channeled from third party funds. This is in accordance with the provisions of Bank Indonesia which stipulates that the amount of FDR must not exceed 110\%. This means that banks may provide funding in excess of the amount of third party funds collected as long as they do not exceed $110 \%$. 
According to the branch manager of PT Bank Muamalat Indonesia, the Kolaka branch has a standardization to determine the related profits to be calculated, there will be costs incurred related to operational costs. The FDR ratio is determined by the bank muamalat which is an average of $2 \%$ above the difference which is an advantage for the bank muamalat (Results of Interview with Mr. Samsu Bahru as Branch Manager of Bank Muamalat Cab. Kolaka on March 5, 2019). This further reinforces that there is a positive and significant effect of the variable $\mathrm{X} 1$ financing to deposit ratio (FDR) on variable $\mathrm{Y}$ profitability at PT Bank Muamalat Indonesia (BMI).

The results of this study are supported by research from Farrashita Aulia and Prasetiono which states that financing to deposit ratio (FDR) has a positive and significant effect on profitability of ROA with results (regression coefficient = 0.547) and significant (0.000 <0.05) This indicates that banks with FDR the high tends to have a higher ROA (Aulia and Prasetiono, 2016). But this research is different from the research conducted by Desi Ariyani with that the research stating that the FDR variable on the profitability of the bank muamalat does not have a partial and insignificant effect where t-count $(-0.874)>$ of $t$-table $(-1.97)$ and significant at $0.388>a=5 \%$ (0.05). (Aryani, 2010). The difference in the results of this study is due to differences in the period and period of the object under study, which is related to the financial ratio report by Desi Ariyani's study with the 2008 financial report. That was the cause in 2008 The global financial crisis has changed the world economic order. The global crisis that began in the United States in 2007, felt the impact throughout the world, including in Indonesia, the impact of the crisis began to be felt, especially towards the end of 2008. After recording economic growth above 6\% up to quarter III-2008, the Indonesian economy began to get pressure heavy in quarter IV-2008.

Second, from the positive regression equation X2 NPF variable has an influence (regression coefficient $=0.005$ ) where the value of $t$ count $0.580<t$ table (2.09) and not significant (0.568> 0.05) So that the decision rejects Ha2 and accepts $\mathrm{Ho} 2$ that there is no direct influence and significant variable X2 NPF to variable Y profitability (ROA). Based on the mean analysis of 2.948261 that the business risk of BMI reflected in the NPF does not significantly affect ROA, this is very possible because the problematic financing of BMI is not so large in nominal value. 
The results of this study are supported by research from Agung Widya Pratama with non-significant results where t-count (-0.719) and significant at $0.476>=5 \%$ (0.05). That the NPF condition is greater in one period does not directly give a decrease in profit in the same period. In this case because financing is the main source of bank income. The high NPF will be able to reduce the turnover of working capital from the bank. So if the bank has a high amount of bad loans, the bank will try to evaluate their performance while temporarily stopping the distribution of funding until the NPF is reduced and using the existing allowance for loss of receivables, so that previously high NPF will be low and ultimately not impact profitability ( Pratama, 2010).

\section{CONCLUSION}

This research concluded that financing to deposit ratio (FDR) and operational expenditure on operating income (BOPO) have affected to profitability on Bank Muamalat Indonesia in 2013-2018.

\section{REFERENCE}

Ardana, Y. (2018). Faktor Eksternal Dan Internal Yang Mempengaruhi Profitabilitas Bank Syariah Di Indonesia. Cakrawala: Junal Studi Islam, Vol. 13. No. 1.

Arifin, Z. (2009). Dasar Dasar Manajemen Bank Syariah, Tanggerang: Alfabeta.

Aryani, D. (2010). Analisis Pengaruh Car, Fdr Bopo Dan Npf Terhadap Profitabilitas Pada PT Bank Muamalat Indonesia Tbk. Al Iqtishad Vol.2. No. $1: 97-124$.

Asiyah, B. N. (2017). Pengaruh Kualitas Portofolio Pembiayaan Terhadap Profitabilitas Bank Mega Syariah. Jurnal An-Nisbah, Vol. 03. Nomor 2: 231-254.

Aulia, F and Prasetiono. (2016). Pengaruh CAR, FDR, NPF, BOPO Terhadap Profitabilitas (Retutn On Equity) (Studi Empiris Pada Bank Umum Syariah Di Indonesia Periode Tahun 2009 2013). Diponegoro Journal Of Management. Vol. 5, No. 1: 1-10.

Dapartemen Agama. (2007). Al- Qur'an Dan Terjemahannya. Bandung: CV Penerbit Diponegoro.

Febrianti and S. Megawati. (2015). Analisis Determinasi Profitabilitas Bank Umum Syariah Periode 2011-2015. Jurnal Ekonomi, Vol. 2, No. 1: 1-17. 
Hartini,, T. (2016). Pengaruh Biaya Operasional Dan Pendapatan Operasional(Bopo) Terhadap Profitabilitas Bank Syariah Di Indonesia. IFinance, Vol. 2. No. 1: 20-34.

Hayati, M. ( 2012). Konstruksi Profit Sharing Dalam Bisnis Syariah”, Jurnal Khatulistiwa, Vol. 2. Nomor 1: 47-67.

Ikatan Bankir Indonesia. (2018). Memahami Bisnis Bank Syariah. Jakarta: PT Gramedia Pustaka Utama.

Ikatan Bankir Indonesia. (2018).. Mengelola Bank Syariah, Cet 2; Jakarta: PT Gramedia Pustaka Utama.

Ikatan Bankir Indonesia. (2018). Strategi Bank Syariah, Cet 1; Jakarta: PT Gramedia Pustaka Utama.

Marimin, A. and A. H. Romdhoni. (2015). Perkembangan Bank Syariah Di Indonesia Jurnal Ilmiah Ekonomi Islam, Vol. 01. No. 2 :75-87.

Mawaddah, N.(2015) Faktor-Faktor Yang Mempengaruhi Profitabilitas Bank Syariah Jurnal Etikonomi, Vol. 14. No. 2:241-256.

Rahmi, N and R. Anggraini. (2013) Pengaruh CAR, BOPO, NPF Dan CSR Disclosure Terhadap Profitabilitas Perbankan Syariah. Jurnal Ilmiah Wahana Akuntansi Vol. 8, No. 2: 171-187.

Haq, R. N. A (2015). Pengaruh Pembiayaan Dan Efisiensi Terhadap Profitabilitas Bank Umum Syariah. Perbanas Review, Vol.1. No. 1: 107-124.

Rizkika, R and V. J, Dillak. (2017). Analisis Faktor-Faktor Yang Mempengaruhi Profitabilitas Bank Umum Syariah Di Indonesia” Jurnal E-Proceeding Of Manageme, Vol. 4. Nomor 3. 2675-2686.

Shihab, M. Quraish. 2009. Tafsir Al-Mishbah. Jakarta. Lentera hati.

Silvia, S. A. (2017). Pengaruh Kualitas Aset Terhadap Profitabilitas Pada Perbankan Syariah Di Indonesia. Al-Falah: Journal of Islamic economics. Vol. 2. Nomor 1: 53-80

Sholihin, A. I. (2013). Buku Pintar Ekonomi Syariah. Jakarta: PT Gramedia Pustaka Utama.

Soemitra, A..( 2015). Bank Dan Lembaga Keuangan Syariah. Jakarta. Prenadamedia Group.

Suryani. (2011). Analisis Pengaruh Financing To Deposit Ratio (FDR)Terhadap Profitabilitas Perbankan Syariah Di Indonesia. Jurnal Walisongo. Vol. 19. No. 1.

Umam, K. (2016). Perbankan Syariah: Dasar-Dasar Dan Dinamika Perkembangannya Di Indonesia. Jakarta: PT Raja Grafindo Persada. 
Ubaidillah. (2016). Analisis Faktor-Faktor Yang Mempengaruhi Profitabilitas Bank Syariah Di Indonesia” Dalam El-Jizya Jurnal Ekonomi Islam, Vol. 4. No. 1.

Yusuf, Y. M and W. S. Mahriana. (2016). Faktor-Faktor Yang Mempengaruhi Tingkat Profitabilitas Bank Pembiayaan Rakyat Syariah (Bprs) Di Aceh, Jurnal Iqtishadia, Vol. 9, Nomor 2. 